\title{
Eksekusi Terhadap Objek Jaminan Fidusia Pasca Putusan Mahkamah Konstitusi Nomor 18/Puu-Xvii/2019 Dan Bentuk Perlindungan Hukum Terhadap Debitur
}

\author{
Fitrian Welfiandi \\ Magister Hukum Universitas Indonesia
}

\begin{tabular}{l}
\hline \hline Article Info \\
\hline Article history: \\
Received 21 Desember 2021 \\
Publish 04 Januari 2022 \\
\\
\hline Keywords: \\
Execution, \\
Fiduciary \\
Debtor Protection. \\
\end{tabular}

Info Artikel

Article history:

Diterima 21 Desember 2021

Publis 04 Januari 2022

\section{Corresponding Author:}

Fitrian Welfiandi

Magister Hukum Universitas Indonesia

\begin{abstract}
Fiduciary guarantee is a guarantee right for movable objects both tangible and intangible and immovable, especially buildings that cannot be encumbered with mortgage rights that remain in the possession of the Fiduciary Giver, as collateral for certain repayments that give priority to Fiduciary Recipients over other creditors. After the Constitutional Court Decision Number 18 / PUU-XVII / 2019 resulted in changes to the provisions of Article 15 paragraph (2), Article 15 paragraph (3), and Elucidation of Article 15 paragraph (3) UUJF, specifically changes to the interpretation of breach of fiduciary violations and executions. This thesis will discuss issues regarding the execution of fiduciary security objects after the Constitutional Court ruling No. 18 / PUU-XVII / 2019 and how the legal protection of debtors for arbitrary creditors' actions.
\end{abstract}

Keywords:

\begin{abstract}
ABSTRAK
Jaminan Fidusia adalah hak jaminan atas benda bergerak baik yang berwujud maupun yang tidak berwujud dan tidak bergerak khususnya bangunan yang tidak dapat dibebani hak tanggungan yang tetap berada dalam penguasaan Pemberi Fidusia, sebagai agunan bagi pelunasan tertentu yang memberikan kedudukan yang diutamakan kepada Penerima Fidusia terhadap kreditur lainnya. Setelah ada Putusan MK Nomor 18/PUU-XVII/2019 mengakibatkan perubahan pada ketentuan Pasal 15 ayat (2), Pasal 15 ayat (3), dan Penjelasan Pasal 15 ayat (3) UUJF, khususnya perubahan mengenai penafsiran wanprestasi dan eksekusi fidusia. Tesis ini akan membahas permasalahan mengenai eksekusi terhadap objek jaminan fidusia pasca putusan Mahkamah Konstitusi Nomor 18/PUU-XVII/2019 serta bagaimana perlindungan hukum terhadap debitur atas tindakan kreditur yang sewenang-wenang.
\end{abstract}

This is an open access article under the Lisensi Creative Commons AtribusiBerbagiSerupa 4.0 Internasional

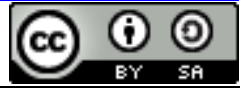

\section{PENDAHULUAN}

Pembangunan ekonomi, sebagai bagian dari pembangunan nasional, merupakan salah satu upaya untuk mencapai masyarakat yang adil dan makmur berdasarkan Pancasila dan UndangUndang Dasar Tahun 1945 (selanjutnya disebut dengan UUD 1945). Dalam rangka memelihara dan meneruskan pembangunan yang berkesinambungan, para pelaku pembangunan baik pemerintah maupun masyarakat, baik perseorangan maupun badan hukum, memerlukan dana yang besar. Seiring dengan meningkatnya kegiatan pembangunan, meningkat pula kebutuhan terhadap pendanaan, yang sebagian besar dana yang diperlukan untuk memenuhi kebutuhan tersebut diperoleh melalui kegiatan pinjam-meminjam

Pada era globalisasi ekonomi saat ini, modal merupakan salah satu faktor yang sangat dibutuhkan untuk memulai dan mengembangkan usaha. Salah satu cara untuk memperoleh modal ataupun dana segar adalah dengan mengambil kredit, baik melalui bank maupun lembaga 
penyedia jasa keuangan lainnya (misalnya lembaga finance untuk kendaraan bermotor). Dalam praktik pihak bank sebagai kreditur lebih menyukai jaminan kebendaan mengingat jaminan ini lebih menguntungkan pihak kreditur karena sifat dari jaminan ini memberikan kepada kreditur kedudukan yang lebih baik dari kreditur-kreditur lain yang tidak mempunyai hak-hak jaminan khusus. Jaminan kebendaan yang diberikan debitur kepada kreditur biasanya berupa barang bergerak dan tidak bergerak. Barang tidak bergerak seperti tanah dan bangunan dapat dibebankan dengan jaminan hak tanggungan, sedangkan untuk barang bergerak dapat menggunakan lembaga jaminan fidusia yang diatur dalam Undang-Undang Nomor 42 Tahun 1999 tentang Jaminan Fidusia (selanjutnya disebut dengan UUJF).

Terbentuknya lembaga fidusia yang tumbuh dalam praktek karena ada kebutuhan akan suatu lembaga jaminan kebendaan bagi benda bergerak berupa benda modal usaha dengan tidak perlu melakukan penyerahan benda jaminannya dan cukup hanya menyerahkan hak miliknya secara kepercayaan. Munculnya lembaga fidusia ini sangat membantu pihak-pihak yang ingin mengembangkan usahanya, karena barang atau benda yang dijadikan jaminan fidusia masih berada pada tangan pemberi fidusia dengan sistem pinjam pakai, walaupun sesungguhnya secara hukum barang tersebut dikuasai atau milik penerima fidusia.

Istilah fidusia berasal dari hukum Romawi, yang dikenal sebagai gadai atas hak kepemilikan benda berdasarkan kepercayaan yang disepakati sebagai jaminan bagi pelunasan utang kreditur. Pada dasarnya keberadaan lembaga jaminan fidusia bagi bangsa Indonesia bukan merupakan suatu lembaga baru. Sudah sejak lama bangsa Indonesia mengenal lembaga jaminan tersebut, bahkan dalam penjelasan atas UUJF diakui bahwa lembaga ini sudah digunakan sejak zaman penjajahan Belanda. Jaminan fidusia pada masa penjajahan dikenal dengan fiducia eigendom overdracht. Penggunaan jaminan ini dahulunya berdasarkan hukum kebiasaan dalam praktek dan diikuit oleh yurisprudensi.

Sistem hukum Indonesia mempunyai hubungan yang erat dengan hukum Belanda karena adanya pertautan sejarah yang didasarkan kepada asas konkordasi (concordantie beginsel). Seperti halnya di Belanda, keberadaan fidusia di Indonesia juga diakui oleh yurisprudensi berdasarkan keputusan Hooggerrecht (HGH) tanggal 18 Agustus 1932 dalam kasus sebagai berikut:

"Pedro Clignent meminjam uang dari Bataafsche Petroeum Maatschapji (BPM) dengan jaminan hak milik atas sebuah mobil berdasarkan kepercayaan. Clignent tetap menguasai mobil itu atas dasar perjanjian pinjam pakai yang akan berakhir jika Clignent lalai membayar utangnya dan mobil tersebut akan diambil BPM. Ketika Clignent benar-benar tidak melunasi utang-utangnya pada waktu yang ditentukan, BPM menuntut penyerahan mobil dari Clignent, namun ditolaknya dengan alasan perjanjian yang dibuat tidak sah. Menurut Clignent perjanjian yang ada adalah gadai, tetapi karena barang gadai dibiarkan tetap dalam kekuasaan debitur maka gadai tersebut menjadi tidak sah sesuai dengan Pasal 1152 ayat (2) BW. Dalam putusannya HGH menolak alasan Clignent bukanlah gadai, melainkan penyerahan hak milik secara kepercayaan atau fidusia yang telah diakui oleh Hoggeraad dalam Bierbrouwerij Arrest, Clignent diwajibkan untuk menyerahkan jaminan itu kepada BPM."

Meskipun lembaga jaminan fidusia dalam sejarahnya tidak lahir dengan undang-undang, tetapi kemudian lembaga fidusia tersebut dikukuhkan dengan undang-undang, yakni UUJF. UUJF lahir atas kebutuhan yang besar dan terus meningkat bagi dunia usaha atas tersedianya dana. Oleh karena itu diperlukan jaminan Fidusia sebagai lembaga jaminan agar mampu memacu pembangunan nasional serta memberikan jaminan kepastian hukum serta mampu memberikan perlindungan hukum bagi pihak berkepentingan.

Pengertian fidusia berdasarkan Pasal 1 angka (1) UUJF adalah:

"pengalihan hak kepemilikan suatu benda atas dasar kepercayaan dengan ketentuan bahwa benda yang hak kepemilikannya dialihkan tersebut tetap dalam penguasaan pemilik benda".

Sedangkan pengertian jaminan fidusia sebagaimana yang disebutkan dalam Pasal 1 angka (2) UUJF adalah: 
"hak jaminan atas benda bergerak baik yang berwujud maupun yang tidak berwujud dan benda tidak bergerak khususnya bangunan yang tidak dapat dibebani hak tanggungan sebagaimana dimaksud dalam Undang-undang Nomor 4 Tahun 1996 tentang Hak Tanggungan yang tetap berada dalam penguasaan Pemberi Fidusia, sebagai agunan bagi pelunasan utang tertentu, yang memberikan kedudukan yang diutamakan kepada Penerima Fidusia terhadap kreditor lainnya."

Jaminan fidusia sama seperti perjanjian penjaminan lain, yang merupakan perjanjian yang bersifat accesoir sebagaimana Pasal 4 UUJF yang menyebutkan:

"jaminan fidusia merupakan perjanjian ikutan dari suatu perjanjian pokok yang menimbulkan kewajiban bagi para pihak untuk memenuhi suatu prestasi."

Adapun benda-benda yang dapat dijadikan objek jaminan fidusia adalah sebagai berikut:

a. Benda tersebut harus dapat dimiliki dan dialihkan secara hukum.

b. Dapat atas benda berwujud.

c. Dapat atas benda tak berwujud, termasuk piutang.

d. Benda bergerak.

e. Benda tidak bergerak yang tidak diikat dengan hak tanggungan.

f. Benda tidak bergerak yang tidak dapat diikatkan dengan hipotek.

g. Baik atas benda yang sudah ada maupun terhadap benda yang akan diperoleh kemudian.

h. Dapat atas satu satuan atau jenis benda.

i. Dapat juga atas lebih dari satu jenis atau satuan benda.

j. Termasuk hasil dari benda yang telah menjadi objek fidusia.

k. Termasuk juga hasil klaim asuransi dari benda yang menjadi objek jaminan fidusia.

1. Benda persediaan dapat juga menjadi objek jaminan fidusia.

Adapun contoh objeknya seperti:

a. Rumah susun berikut tanah tempat bangunan yang merupakan kesatuan tanah hak pakai milik negara.

b. Hak pakai atas tanah negara beserta rumah susun yang dibangun.

c. Kapal yang tidak terdaftar.

d. Perumahan.

e. Tanah girik.

Menurut Munir Fuady, jaminan fidusia mengandung beberapa prinsip penting, yaitu:

a. Bahwa secara riil, pemegang fidusia hanya berfungsi sebagai pemegang jaminan saja, bukan sebagai pemilik yang sebenarnya.

b. Hak pemegang fidusia untuk mengeksekusi barang jaminan baru ada jika ada wanprestasi dari pihak debitur.

c. Apabila utang sudah dilunasi, maka objek jaminan fidusia mesti dikembalikan kepada pihak pemberi fidusia.

d. Jika hasil penjualan (eksekusi) barang fidusia melebihi jumlah utangnya, maka sisa hasil penjualan harus dikembalikan kepada pemberi fidusia.

Sebagai jaminan dan perlindungan kepastian hukum dalam pemberian kredit, dalam UUJF turut diatur mengenai jaminan eksekusi terhadap objek fidusia. Pasal 15 ayat (2) UUJF merupakan dasar kekuatan eksekutorial Sertifikat Jaminan Fidusia dengan putusan pengadilan yang telah berkekuatan hukum tetap. Oleh karena itu, dalam Sertifikat Jaminan Fidusia dicantumkan kata kata "DEMI KEADILAN BERDASARKAN KETUHANAN YANG MAHA ESA" layaknya sebuah putusan pengadilan. Hal ini sebagaimana yang diatur dalam Pasal 15 ayat (1) UUJF. Selanjutnya, Pasal 15 ayat (3) UU 42/1999 menyatakan penerima fidusia mempunyai hak untuk menjual benda yang menjadi objek jaminan fidusia atas kekuasaannya sendiri apabila debitur cidera janji.

Berdasarkan ketentuan Pasal 29 UUJF, dapat disimpulkan bahwa dalam eksekusi fidusia dapat dilakukan melalui beberapa cara, yaitu:

a. Secara fiat eksekusi (dengan memakai titel eksekutorial), yaitu melalui penetapan pengadilan. 
b. Secara parate eksekusi, yaitu dengan menjual benda yang dijadikan objek jaminan fidusia di depan pelelangan umum tanpa memerlukan penetapan pengadilan.

c. Dijual di bawah tangan oleh pihak kreditur sendiri.

Materi dalam Pasal 15 ayat (2) UUJF memiliki persoalan konstitusionalitas. Pasalnya, posisi debitur yang keberatan menyerahkan objek jaminan fidusia lebih lemah karena kreditur dapat mengeksekusinya tanpa mekanisme eksekusi pengadilan. Tindakan sepihak ini berpotensi menimbulkan tindakan sewenang-wenang baik fisik maupun psikis terhadap debitur/pemberi fidusia. Selain itu, dalam Pasal 15 ayat (3) UUJF, frasa cedera janji tidak menjelaskan faktorfaktor yang menyebabkan pemberi fidusia mengingkari kesepakatan dengan penerima fidusia. Hal ini dapat mengakibatkan hilangnya hak pemberi fidusia untuk membela diri dan menjual objek dengan harga wajar.

Dalam rangka eksekusi fidusia, Kapolri sendiri sudah mengeluarkan Peraturan Kapolri Nomor 8 Tahun 2011 tentang Pengamanan Eksekusi Jaminan Fidusia yang sudah berlaku sejak 22 Juni 2011. Namun dalam praktik pelaksanaan eksekusi terhadap objek Jaminan Fidusia kerap menimbulkan ketidak pastian hukum. Khususnya untuk penerapan Pasal 15 ayat (2) dan (3) UUJF karena sering mengabaikan perlindungan keadilan bagi debitur.

Seperti kasus yang dialami oleh Aprilliani Dewi dan Suri Agung Prabowo. Kasus bermula saat mereka telah melakukan Perjanjian Pembiayaan Multiguna atas penyediaan dana pembelian satu unit mobil Toyota Alphard V Model 2.4 A/T 2004 di PT. Astra Sedaya Finance (PT ASF). Sesuai perjanjian yang telah disepakati, Aprilliani dan Suri berkewajiban membayar utang kepada PT ASF senilai Rp 222.696.000 dengan cicilan selama 35 bulan terhitung sejak 18 November 2016. Selama 18 November 2016 hingga 18 Juli 2017, Pemohon telah membayarkan angsuran tepat waktu. Namun, pada 10 November 2017, PT ASF mengirim perwakilan untuk mengambil kendaraan mereka dengan dalil/alasan wanprestasi. Atas perlakuan tersebut, Pemohon mengajukan surat pengaduan atas tindakan yang dilakukan perwakilan PT ASF. Namun tidak ditanggapi hingga mendapat beberapa perlakuan tidak menyenangkan.

Menerima perlakuan tersebut, keduanya berupaya mengambil langkah hukum dengan mengajukan gugatan ke Pengadilan Negeri Jakarta Selatan (PN Jaksel) pada 24 April 2018. Dasar gugatannya, perbuatan melawan hukum dengan nomor registrasi perkara 345/PDT.G/2018/PN.Jkt.Sel. Pengadilan pun mengabulkan gugatan Aprilliani dan Suri dengan menyatakan PT ASF telah melakukan perbuatan melawan hukum. Namun, PT ASF tetap melakukan penarikan paksa kendaraan Pemohon disaksikan pihak kepolisian. Padahal, sesuai hasil putusan pengadilan itu, pihak PT ASF tidak bisa mengambil mobil itu.

Pemohon menganggap PT ASF telah berlindung di balik Pasal 15 UUJF, sehingga kemudian Pemohon mengajukan uji materi terhadap UUJF kepada MK karena merasa hak konstitusionalnya telah dilanggar. Pada tanggal 6 Januari 2020, Mahkamah Konstitusi berdasarkan Putusan Nomor 18/PUU-XVII/2019 telah mengabulkan permohonan uji materi terhadap UUJF khususnya ketentuan Pasal 15 ayat (2), Pasal 15 ayat (3), serta Penjelasan Pasal 15 ayat (2).

Berdasarkan uraian diatas, maka menarik untuk membahas permasalahan mengenai eksekusi terhadap objek jaminan fidusia pasca putusan Mahkamah Konstitusi Nomor 18/PUUXVII/2019 serta bagaimana perlindungan hukum terhadap debitur atas tindakan kreditur yang sewenang-wenang.

\section{KAJIAN PUSTAKA}

Prinsip-prinsip jaminan fidusia

Jaminan Fidusia sesuai UUJF adalah hak jaminan atas benda bergerak baik yang berwujud maupun yang tidak berwujud dan tidak bergerak khususnya bangunan yang tidak dapat dibebani hak tanggungan yang tetap berada dalam penguasaan Pemberi Fidusia, sebagai agunan bagi pelunasan tertentu yang memberikan kedudukan yang diutamakan kepada Penerima Fidusia terhadap kreditur lainnya. 
Dalam UUJF, pembentuk Undang-Undang tidak mencantumkan secara tegas asas-asas hukum jaminan fidusia yang menjadi fundamen dari pembentukan norma hukumnya. Oleh karena itu untuk menemukan asas-asas hukum jaminan fidusia dicari dengan jalan menelaah pasal demi pasal dari UUJF tersebut.

Adapun asas pokok dalam Jaminan Fidusia, yaitu:

a) Asas Spesialitas atas Fixed Loan.

Asas ini ditegaskan dalam Pasal 1 dan 2 UUJF. Objek jaminan fidusia merupakan agunan atau jaminan atas pelunasan utang tertentu yang memberikan kedudukan yang diutamakan kepada penerima fidusia terhadap kreditur lainnya. Oleh karena itu, objek jaminan fidusia harus jelas dan tertentu pada satu segi, dan pada segi lain harus pasti jumlah utang debitur atau paling tidak dipastikan atau diperhitungkan jumlahnya (verrekiningbaar, deductable).

b) Asas asscesoir.

Menurut Pasal 4 UUJF, jaminan fidusia adalah perjanjian ikutan dari perjanjian pokok (principal agreement). Perjanjian pokoknya adalah perjanjian utang, dengan demikian keabsahan perjanjian jaminan fidusia tergantung pada perjanjian pokok, dan penghapusan benda objek jaminan fidusia tergantung pada penghapusan perjanjian pokok.

c) Asas Droit de Suite.

Menurut Pasal 27 ayat (2) UUJF dinyatakan jaminan fidusia tetap mengikuti benda yang menjadi objek jaminan fidusia dalam tangan siapapun berada, kecuali keberadaannya pada tangan pihak ketiga berdasarkan pengalihan hak atas piutang atau cessie berdasarkan Pasal 613 KUHPdt. Dengan demikian, hak atas jaminan fidusia merupakan hak kebendaan mutlak atau in rem bukan hak in personam.

d) Asas Preferen (Droit de Preference).

Pengertian Asas Preferen atau hak didahulukan ditegaskan dalam Pasal 27 ayat (1) UUJF yaitu memberi hak didahulukan atau diutamakan kepada penerima fidusia terhadap kreditur lain untuk mengambil pemenuhan pembayaran pelunasan utang atas penjualan benda objek fidusia. Kualitas hak didahulukan penerima fidusia, tidak hapus meskipun debitur pailit atau dilkuidasi sebagaimana diatur dalam Pasal 27 ayat (3) UUJF.

\section{Kedudukan kreditur fidusia yang tidak mendaftarkan jaminan fidusia}

Kreditur adalah orang yang mempunyai piutang karena perjanjian atau undang-undang yang dapat ditagih di muka pengadilan. Di mana kreditur yang dimaksud dapat bersifat perorangan atau badan hukum.

Dalam hukum perdata secara garis besar kreditur dapat dibagi menjadi tiga, yaitu:

a. Kreditur Sparatis adalah kreditur pemegang hak jaminan kebendaan yang dapat bertindak sendiri;

b. Kreditur Preferen adalah kreditur yang memiliki hak istimewa atau hak prioritas.

c. Kreditur Konkuren adalah kreditur yang harus berbagi dengan para kreditor lainnya secara proporsional, yaitu menurut perbandingan besarnya masing-masing tagihan, dari hasil penjualan harta kekayaan debitur yang tidak dibebani dengan hak jaminan.

Ada beberapa pasal yang menjelaskan ketentuan tentang penggolongan kreditur ini, yakni terdapat dalam Pasal 1132, Pasal 1134, Pasal 1135, Pasal 1136, Pasal 1138, dan Pasal 1139 Kitab Undang-Undang Hukum Perdata (selanjutnya disebut dengan KUHPdt).

Sejalan dengan prinsip memberikan kepastian hukum, maka UUJF mengambil prinsip pendaftaran jaminan fidusia. Pendaftaran tersebut diharapkan memberikan kepastian hukum kepada pemberi dan penerima fidusia maupun kepada pihak ketiga. Pemberian sifat hak kebendaan kepada hak kreditur penerima fidusia, dapat dikeluarkannya grosse sertifikat jaminan fidusia, diberikannya hak parate eksekusi dan diberikan status sebagai kreditur separatis menunjukkan maksud pembuat undang-undang untuk memberikan kedudukan yang kuat kepada kreditur.

Pendaftaran dilakukan melalui suatu permohonan yang ditujukan kepada Kantor Pendaftaran Fidusia (KPF) yang untuk pertama kalinya akan diadakan di Jakarta, yang wilayah 
kerjanya meliputi seluruh Indonesia (Pasal 12 ayat (1) dan ayat (2) UUJF). Pendaftaran dicatat dalam buku daftar fidusia pada tanggal yang sama dengan tanggal penerimaan permohonan pendaftaran (Pasal 14 ayat (1) UUJF) dan tanggal tersebut akan mempunyai dampak hukum yang besar sekali, karena tanggal tersebut menentukan lahirnya jaminan fidusia (Pasal 14 ayat (3) UUJF).

Seiring dengan adanya berbagai perubahan dalam dunia fidusia, dan Mengingat betapa pentingnya fungsi pendaftaran bagi suatu jaminan hutang termasuk jaminan hutang termasuk jaminan fidusia ini, maka UUJF kemudian mengaturnya dengan mewajibkan setiap jaminan fidusia untuk didaftarkan pada pejabat yang berwenang.

Kreditur fidusia yang tidak mendaftarkan objek jaminan fidusia tidak dapat dikatakan sebagai kreditur preferen, oleh karena itu kreditur tersebut tidak dapat memperoleh pelunasan yang lebih didahulukan dari kreditur-kreditur lainnya tehadap objek jaminan fidusia tersebut. Untuk itu dia hanya dapat dikatagorikan sebagai kreditur konkuren terhadap objek jaminan fidusia yang tidak didaftarkan. Sehingga dengan demikian dapat diperlakukan terhadap kreditur tersebut pasal 1131 KUHPdt, dimana dia harus berbagi dengan kreditur lain dari obyek jaminan fidusia untuk utang-utangnya debitur terhadap krediturnya.

\section{METODE PENELITIAN}

Metode pendekatan yang digunakan adalah yuridis-normatif, dengan jenis penelitian dogmatik, bentuk penelitian perskriptif hubungan hukum. Spesifikasi penelitian ini yaitu deskriptif-analitis. Metode pengumpulan data yang digunakan melalui metode library research (metode kepustakaan) dengan menguji bahan dokumen dan bahan pustaka yang digunakan dalam penelitian ini. Data dianalisis secara kualitatif-normatif, meneliti dengan jalan menafsirkan dan membangun pernyataan yang terdapat dalam dokumen per-undang-undangan. Metode analisis kualitatif, dibangun berdasarkan data sekunder yang berupa teori, makna dan substansinya dari berbagai literatur, peraturan perundang-undangan, dan data primer yang diperoleh dari wawan-cara, pengamatan dan studi lapangan, kemudian dianalisis dengan normatifnya undang-undang, teori dan pendapat pakar yang berkaitan, sehingga didapat kesimpulan tentang pengertian kebijakan hukum pidana yang berkaitan deng-an pengelolaan lingkungan hidup dan pengentasan masalah-masalah lingkungan hidup di masyarakat di masa mendatang.

\section{HASIL PENELITIAN DAN PEMBAHASAN}

\subsection{Eksekusi Terhadap Objek Jaminan Fidusia Sebelum Putusan Mahkamah Konstitusi Nomor 18/PUU-XVII/2019}

Salah satu ciri jaminan fidusia adalah kemudahan dalam pelaksanaan eksekusinya yaitu apabila pihak pemberi fidusia cidera janji. Apabila debitur cidera janji maka menurut Pasal 15 ayat (3) UUJF penerima fidusia mempunyai hak untuk menjual benda yang menjadi obyek jaminan fidusia atas kekuasaannya sendiri. Eksekusi adalah pelaksanaan dari hak-hak kreditur dalam perutangan yang tertuju terhadap harta kekayaan debitur manakala perutangan tersebut tidak dipenuhi secara sukarela oleh debitur.

Pasal 11 UUJF menentukan bahwa benda yang berada di dalam wilayah negara Republik Indonesia yang dibebani jaminan fidusia wajib didaftarkan. Pendaftaran dilakukan pada Kantor Pendaftaran Jaminan Fidusia. Pendaftaran merupakan hal wajib yang harus dipenuhi sebagai syarat lahirnya jaminan fidusia. Pendaftaran tersebut mempunyai arti yuridis sebagai suatu rangkaian yang tidak terpisah dari proses terjadinya perjanjian jaminan fidusia.

Suatu objek jaminan fidusia tidak didaftarkan maka akan menimbulkan suatu resiko tertentu, salah satunya adalah eksekusi tidak dapat dilakukan karena syarat dalam pengeksekusian harus adanya sertifikat jaminan fidusia yang didapatkan pada saat pendaftaran jaminan fidusia. Sertifikat Jaminan fidusia mempunyai kekuatan eksekutorial yang sama dengan putusan pengadilan yang telah memperoleh kekuatan hukum tetap 
berdasarkan titel eksekutorial tersebut penerima fidusia dapat langsung melaksanakan eksekusi melalui pelelangan umum atas objek jaminan fidusia tanpa melalui pengadilan.

Eksekusi jaminan fidusia diatur dalam Pasal 29 sampai dengan Pasal 34 UUJF. Berdasarkan aturan tersebut, ada 3 (tiga) cara eksekusi jaminan fidusia, yaitu:

a. Pelaksanaan titel eksekutorial oleh penerima fidusia sebagaimana dimaksud dalam Pasal 15 ayat (2) oleh Penerima Fidusia.

Dalam sertifikat Jaminan Fidusia yang diterbitkan Kantor Pendaftaran Fidusia dicantumkan kata-kata " Demi Keadilan Berdasarkan Ke-Tuhanan Yang Maha Esa". Sertifikat jaminan fidusia ini mempunyai kekuatan eksekutorial yang sama dengan putusan pengadilan yang telah memperoleh kekuatan hukum yang tetap.

Dengan demikian pelaksanaan titel eksekusi (alas hak eksekusi) oleh penerima fidusia mengandung 2 (dua) syarat utama yakni:

1) Debitur atau Pemberi Fidusia cidera janji

2) Ada sertifikat Jaminan Fidusia yang mencantumkan "Demi Keadilan Berdasarkan Ketuhanan Yang Maha Esa".

b. Penjualan benda yang menjadi objek jaminan fidusia atas kekuasaan penerima fidusia sendiri melalui pelelangan umum;

Apabila debitur cidera janji, penerima fidusia mempunyai hak menjual benda obyek jaminan fidusia atas kekuasaanya sendiri. Penjualan dengan cara ini dikenal dengan nama lembaga Parate Eksekusi dan diharuskan dijual melalui pelelangan umum, dengan demikian Parate Eksekusi kurang lebih adalah kewenangan yang diberikan (oleh undang-undang atau putusan pengadilan) kepada salah satu pihak untuk melaksanakan sendiri secara paksa isi perjanjian manakala pihak yang lainnya wanprestasi.

c. Penjualan di bawah tangan yang dilakukan berdasarkan kesepakatan pemberi dan penerima fidusia.

Eksekusi jaminan fidusia dengan cara penjualan di bawah tangan adalah suatu perkembangan sistem eksekusi yang sebelumnya juga telah dianut dalam eksekusi Hak Tanggungan.

Seperti halnya dalam undang-undang hak tanggungan maka dalam undangundang fidusia ini penjualan di bawah tangan terhadap obyek fidusia juga mengandung beberapa persyaratan yang relatif berat untuk dilaksanakan.

\subsection{Eksekusi Terhadap Objek Jaminan Fidusia Pasca Putusan Mahkamah Konstitusi Nomor 18/PUU-XVII/2019}

Setelah ada Putusan MK Nomor 18/PUU-XVII/2019 yang mengakibatkan konstitusional bersyarat Pasal 15 ayat (2), Pasal 15 ayat (3), dan Penjelasan Pasal 15 ayat (3) UUJF, khususnya perubahan mengenai penafsiran wanprestasi dan eksekusi fidusia.

Putusan MK a quo menjadikan titel eksekutorial tidak serta merta berkekuatan sebagaimana putusan pengadilan yang telah memiliki kekuatan hukum yang mengikat dalam kondisi tertentu sebagaimana ditegaskan dalam Amar Putusan. Terkait Pasal 15 ayat (2) UUJF berdasarkan putusan MK tersebut maka terhadap jaminan fidusia yang tidak ada kesepakatan tentang cidera janji (wanprestasi) dan debitur keberatan menyerahkan secara sukarela objek yang menjadi jaminan fidusia, maka segala mekanisme dan prosedur hukum dalam pelaksanaan eksekusi Sertifikat Jaminan Fidusia harus dilakukan dan berlaku sama dengan pelaksanaan eksekusi putusan pengadilan.

Selanjutnya ketentuan cidera janji sebagaimana diatur dalam Pasal 15 ayat (3) UUJF tidak ditentukan secara sepihak oleh kreditur melainkan atas dasar kesepakatan antara kreditur dengan debitur atau atas dasar upaya hukum yang menentukan telah terjadinya cidera janji.

4.3 Perlindungan Hukum Terhadap Debitur Atas Tindakan Kreditur Yang Melakukan Eksekusi Tanpa Melalui Prosedur Sebagaimana Yang Diatur Dalam Putusan Mahkamah Konstitusi Nomor 18/PUU-XVII/2019 
Dalam melakukan eksekusi fidusia, seringkali banyak lembaga pembiayaan yang melaksanakan penarikan objek secara sepihak. Penarikan ini dilakukan tanpa melibatkan jurusita dari pengadilan. Hal ini seringkali menjadi permasalahan di lapangan antara lembaga pembiayaan dengan konsumen.

Ketika terjadinya kerugian pada konsumen yang ditimbulkan oleh perbuatan pelaku usaha, Undang-undang Nomor 8 Tahun 1999 tentang Perlindungan Konsumen ini menjadi solusi agar konsumen dapat dilindungi, dan dijamin kepastian hukumnya. Eksekusi yang dilakukan oleh tenaga penagihan secara sepihak ini, tentu tidak sesuai dengan asas perlindungan konsumen. Asas-asas itu berupa keamanan, keselamatan konsumen dan kepastian hukum. Asas yang dimaksud sesuai dengan yang tertera dalam Pasal 2 Undangundang No. 8 Tahun 1999 tentang Perlindungan Konsumen.

\section{KESIMPULAN}

Setelah ada Putusan MK Nomor 18/PUU-XVII/2019 yang mengakibatkan konstitusional bersyarat Pasal 15 ayat (2), Pasal 15 ayat (3), dan Penjelasan Pasal 15 ayat (3) UUJF, khususnya perubahan mengenai penafsiran wanprestasi dan eksekusi fidusia. Putusan MK a quo menjadikan titel eksekutorial tidak serta merta berkekuatan sebagaimana putusan pengadilan yang telah memiliki kekuatan hukum yang mengikat dalam kondisi tertentu sebagaimana ditegaskan dalam Amar Putusan. Terkait Pasal 15 ayat (2) UUJF berdasarkan putusan MK tersebut maka terhadap jaminan fidusia yang tidak ada kesepakatan tentang cidera janji (wanprestasi) dan debitur keberatan menyerahkan secara sukarela objek yang menjadi jaminan fidusia, maka segala mekanisme dan prosedur hukum dalam pelaksanaan eksekusi Sertifikat Jaminan Fidusia harus dilakukan dan berlaku sama dengan pelaksanaan eksekusi putusan pengadilan. Selanjutnya ketentuan cidera janji sebagaimana diatur dalam Pasal 15 ayat (3) UUJF tidak ditentukan secara sepihak oleh kreditur melainkan atas dasar kesepakatan antara kreditur dengan debitur atau atas dasar upaya hukum yang menentukan telah terjadinya cidera janji.

Ketika terjadinya kerugian pada konsumen yang ditimbulkan oleh perbuatan pelaku usaha, Undang-undang Nomor 8 Tahun 1999 tentang Perlindungan Konsumen ini menjadi solusi agar konsumen dapat dilindungi, dan dijamin kepastian hukumnya. Eksekusi yang dilakukan oleh tenaga penagihan secara sepihak ini, tentu tidak sesuai dengan asas perlindungan konsumen. Asas-asas itu berupa keamanan, keselamatan konsumen dan kepastian hukum. Asas yang dimaksud sesuai dengan yang tertera dalam Pasal 2 Undang-undang No. 8 Tahun 1999 tentang Perlindungan Konsumen.

\section{DAFTAR PUSTAKA}

\section{Buku}

, Hukum Jaminan, Hak-hak Jaminan Pribadi, (Bandung: Citra Aditya Bakti, 1996).

Abdul R. Saliman, Hukum Bisnis Untuk Perusahaan: Teori dan Contoh Kasus, (Jakarta: Kencana, 2005).

Amirudin dan Zainal Asikin, Pengantar Metode Penelitian Hukum, (Jakarta: Raja Grafindo Persada, 2004).

C.S.T.Kansil, Pengantar Ilmu Hukum dan Tata Hukum Indonesia, (Jakarta : Balai Pustaka, 1982).

Djuhaendah Hasan, Lembaga Jaminan Kebendaan Bagi Tanah dan Benda Lain yang Melekat Pada Tanah Dalam Konsepsi Penetapan Asas Pemisahan Horizontal, (Bandung: Citra Aditya Bakti, 1996).

Gatot Supramono, Perjanjian Utang Piutang, (Jakarta: Prenadamedia Group, 2013).

Gunawan Widjaja dan Ahmad Yani, Jaminan Fidusia, (Jakarta: Raja Grafindo Persada, 2000).

J. Satrio, Hukum Jaminan Hak Jaminan Kebendaan, (Bandung: Citra Aditya Bakti, 2002).

Mariam Darus Bardrulzaman, Aneka Hukum Bisnis, (Bandung: Alumni, 2014).

Marjan Miharja, Kompilasi Pemikiran Hukum di Indonesia, (Pasuruan: Qiara Media, 2019). 
Munir Fuady, Hukum Bisnis Dalam Teori dan Praktek, (Bandung: Citra Aditya Bakti, 2017).

Soerjono Soekanto, Pengantar Penelitian Hukum, (Jakarta: Penerbit Universitas Indonesia, 2010).

Sri Mamudji, et al., Metode Penelitian dan Penulisan Hukum, (Jakarta: Badan Penerbit Fakultas Hukum Universitas Indonesia, 2005).

Titik Triwulan Tutik, Hukum Perdata Dalam Sistem Hukum Nasional, (Jakarta: Prenadamedia Group, 2008).

Waldi Nopriansyah, Hukum Bisnis Di Indonesia: Dilengkapi Dengan Hukum Bisnis Dalam Persfektif Syariah, (Jakarta: Prenadamedia, 2019).

\section{Peraturan Perundang-Undangan}

Kitab Undang-Undang Hukum Perdata

Peraturan Kapolri Nomor 8 Tahun 2011 tentang Pengamanan Eksekusi Jaminan Fidusia

Putusan Mahkamah Konstitusi Nomor 18/PUU-XVII/2019

Undang-Undang Dasar Tahun 1945

Undang-Undang Nomor 42 Tahun 1999 tentang Jaminan Fidusia 